\title{
AVIACIJOS SEKTORIAUS IŠŠŪKIAI ATEITIES SPECIALISTŲ RENGIMUI
}

\author{
Liudmila LOBANOVA*, Rytis APANAVIČIUS \\ Vilniaus Gedimino technikos universitetas, Verslo vadybos fakultetas, \\ Vadybos katedra, Sauletekio al. 11, LT-10223, Vilnius, Lietuva \\ "El.paštas liudmila.lobanova@vgtu.lt
}

\begin{abstract}
Santrauka. Straipsnyje aptariami aviacijos sektoriaus iššŭkiai, keičiantys ateities specialistų poreikį. Pirmoje straipsnio dalyje analizuojami aviacijos sektoriaus iššūkiai pasaulyje ir Lietuvoje: saugos ir saugumo, nauju technologijų, tvarios plètros bei besikeičiančių vartotojų poreikių aspektais. Antroje dalyje pateikta aviacijos specialistų rengimo ir licencijavimo sistemos analizé, pabréžiant teisinius ir rinkos keliamus reikalavimus aviacijos specialistų kompetencijoms. Trečioje dalyje pateiktos mokslininkų iž̌valgos apie ateities iššūkius, keičiančius aviacijos specialistų kompetencijų poreikius: žmogiškieji veiksniai ir jų ịtaka aviacijos saugai, žmogaus ir dirbtinio intelekto pilotavimo sistemu suderinamumas ir patikimumas aviacijoje, bei iššūkiai, su kuriais susiduria aviacijos specialistai, dirbantys skirtinguose aviacijos sektoriuose. Mokslininkų atlikti tyrimai parodè, kad asmeninès žmogiškosios savybès taip pat yra svarbios aviacijos specialistų darbe, ypatingai užtikrinant skrydžių saugą. Dirbtinio intelekto sistemos padeda orlaivių pilotams atlikti didelio informacijos srauto apdorojimo užduotis, ịvertinti situaciją ir priimti teisingus sprendimus. Perèjimas prie labiau automatizuotų ar autonominių valdymo sistemų dar labiau padidintų aviacijos saugą ir palaikytų naujus pokyčius svarbiausiose vienpiločių orlaivių technologijos srityse. Išvadose konstatuojama, kad aviacijos pramonè susidurs su daugeliu iššūkių, susijusių su darbo jèga. Nežinoma, kokiu laipsniu technologijos pakeis darbuotojus, tačiau technologijos turès įtakos visų aviacijos specialistų darbo pobūdžiui, todèl pramonè turi užtikrinti, kad nauji darbuotojai ir esamas personalas turètų kompetencijas, ne tik pagal reikalavimus, kurie yra apibréžti teisiniuose reglamentuose, bet ir aktualūs šiuolaikineje aviacijos rinkoje.
\end{abstract}

Reikšminiai žodžiai: aviacija, specialistų kompetencija, žmogiškieji veiksniai, technologijos.

\section{Ivadas}

Per pastaruosius kelerius metus pasaulinëje aviacijos pramonëje stebimas ženklus augimas. Tarptautinè oro transporto asociacija (International Air Transport Association - IATA) prognozuoja, kad mažiau nei per 20 metu bendras keleivių skaičius padidès dvigubai ir iki $2034 \mathrm{~m}$. pabaigos pasieks stulbinantį 7,3 milijardo žmonių skaičiu (IATA, 2018). Siekdamos patenkinti augančią paklausą, oro linijų bendrovès siūlo daugiau skrydžiu ir atnaujina savo orlaivius, itraukia daugiau maršrutų ir tobulina rinkai siūlomus produktus bei paslaugas. Milžiniškais žingsniais plečiantis aviacijos sektoriui naujų specialistų poreikis ženkliai auga. „Boeing“ kompanija prognozuoja, kad iki 2040 metų pasaulyje reikès virš 800000 pilotų, apie 150000 jų reikès Europoje. Orlaivių techninès priežiūros inžinierių poreikis išaugs iki 769000, Europoje - iki 137000. Skrydžių palydovų poreikis irgi augs reikès 914000, iš jų Europoje 194000 (Boeing, 2019). Remiantis kompanijos „Airbus“ duomenimis, pasaulio keleivinių ir krovininių orlaiviu parkas iki 2038 m. padidès daugiau nei dvigubai - nuo dabartinio beveik 23000 iki 48000, o eismas kasmet padidess 4,3 proc., taip pat prireiks 550000 naujų pilotų ir 640000 naujų technikų (Airbus, 2019).

Keleiviu pasirenkančiu oro transportą skaičiaus didejjimas stebimas ir Baltijos šalyse bei Lietuvoje. Valstybès įmonès Lietuvos oro uostai $2019 \mathrm{~m}$. tarpinès finansinès ataskaitos duomenimis $2019 \mathrm{~m}$. I pusmetị Lietuvos oro uostuose aptarnautų keleivių skaičius siekẻ 3,1 mln., t. y. 5 proc. daugiau keleivių, nei $2018 \mathrm{~m}$. I pusmetį. $2018 \mathrm{~m}$. I pusmečio rezultatas buvo $2,9 \mathrm{mln}$. keleivių ( +16 proc. lyginant su $2017 \mathrm{~m}$. I pusmečiu). 2019 metais Lietuvos oro uostuose skrydžiai buvo vykdomi 91 maršrutu (LTOU, 2019). Todèl jau dabar matomas augantis naujų pilotu ir skrydžių vadovų poreikis Lietuvoje.

Lietuvos transporto kompetencijų agentūros $2019 \mathrm{~m}$. parengtame 2020-2024 m. strateginiame veiklos plane teigiama, kad Europoje iki 2036 m. aviacijos inžinierių poreikis išaugs iki 118 tūkst. Lietuvoje šioje srityje šiuo metu yra apie 2000 darbuotojų - orlaivių remonto mechanikų, inžinierių ir elektronikos sistemų priežiūros specialistų. Specialistai yra itin paklausūs, o dèl jų konkuruoja ne tik Lietuvos, bet ir viso pasaulio kompanijos. Atsižvelgiant $\mathfrak{i}$ industrijos poreikius ir Lietuvai siekiant ịsitvirtinti orlaiviu remonto industrijoje bei toliau kurti 
aukštos pridètinès vertès darbo vietas, planuojama, kad parengiamu specialistu skaičius turi padvigubèti - nuo dabar parengiamų 150-200 iki beveik 400 specialistu per metus" (TKA, 2019).

Skaitmenizavimo pokyčiai daro didelę ittaką aviacijos industrijai. Ateityje planuojama daugelį operacijų atlikti naudojant dirbtini intelektą ar automatizavimą, kurie pakeistų dabar ịprastai darbuotojų atliekamas funkcijas. Aviacijos specialistams tektų užduotis prižiūrèti dirbtinị intelektą, kuris automatizuotai gali atlikti jam paskirtas užduotis ir laikytis konkrečių nurodymų. Atsirandant naujoms technologijoms industrijai reikès investuoti į nauju būsimų aviacijos vadovų ir darbuotojų igūdžių lavinimą bei paaiškinti būsimiems specialistams darbo šiame sektoriuje pranašumus, todèl IATA turètų parengti mokymų gaires naujos kartos oro linijų darbuotojams ir vartotojams (IATA, 2018).

Aukščiau apibrěžtos rinkos tendencijos akivaizdžiai rodo, kad aviacijos sektoriaus specialistų poreikis tiek pasaulyje, tiek Lietuvoje auga, ir yra aktuali problema. Besikeičiančios technologijos kelia iššūkius ne tik techninei aviacijos sektoriaus pusei - naujų orlaivių kūrimui, oro uostų infrastruktūros plètrai, bet ir formuoja besikeičiančiu kompetenciju poreiki rengiant ateities aviacijos specialistus. Manoma, kad aukščiausias kompetencijas turinčius aviacijos specialistus gali sėkmingai parengti aukštosios mokyklos glaudžiai bendradarbiaudamos su aviacijos kompanijomis. Galimas sprendimo būdas galbūt galètų būti ir neformalių kompetencijų ịgijimas įmonèse, kurios būtų licencijuotos vykdyti šią veiklą.

Šio straipsnio tikslas - išanalizuoti aviacijos sektoriaus iššūkius, keičiančius aviacijos specialistų poreikị. Tyrimui atlikti pasirinktas literatūros ir teisinio reglamentavimo dokumentų analizės metodas.

\section{Aviacijos sektoriaus iššūkiai pasaulyje ir Lietuvoje}

Aviacijos pramonės svarba yra reikšminga: sukuria apie 66 milijonus darbo vietų ir 2,7 trilijono USD ekonominę naudą kasmet. Tai reiškia, kad ši pramonè gali būti prilyginta prie tokių šalių, kaip Šveicarija ir Argentina, indèlio ị pasaulio ekonomiką (IATA, 2019). Ir nors aviacijos sektoriui prognozuojamas didžiulis augimas, yra tam tikrų išš̄ikių ir problemų, kurios turi būti sprendžiamos.

\subsection{Saugumas}

Sauga ir saugumas yra didžiausi iššūkiai, su kuriais susiduria ši pramonè. Taip yra todèl, kad vis dar vyrauja visuotinis terorizmas, lengvai gali būti nukreiptas $\mathfrak{i}$ aviacijos sektorių. Oro uostai, vyriausybės ir oro liniju bendrovės turi ieškoti naujų ir novatoriškų būdų, kaip padidinti saugumą nepakenkiant keleivių aptarnavimui ir bendram keleivių patogumui. Todèl aviacijos saugos ir saugumo standartų igyvendinimo užtikrinimas yra vienas iš prioritetinių uždavinių. Civilinès aviacijos priežiūra vykdoma vadovaujantis Tarptautinès civilinès aviacijos organizacijos (ICAO), Europos Parlamento (EP), Europos Tarybos (ET) bei Europos Komisijos (EK) išleistais civilinès aviacijos priežiūros srityje veikiantiems subjektams taikomais reglamentais, kurie yra nuolat atnaujinami, Europos Komisijos sprendimais, komunikatais. Todèl Lietuvos ir tarptautiniu lygiu vykstantys bendro planavimo procesai bei nuolat tobulinamų ar priimamų naujų tarptautinių ir nacionalinių teisès aktų, techninių ir organizacinių reikalavimų civilinès aviacijos priežiūros srityje igyvendinimas turi ir ateityje turès didelę ịtaką (TKA, 2019b). Lietuva taip pat yra įsipareigojusi dalyvauti ES vykdomose aviacijos programose: bendro Europos dangaus, trečiujų šalių orlaivių patikros, aviacijos saugumo reikalavimų taikymo plètros ir kt.

\subsection{Technologijos}

Technologijų pažanga yra dar vienas didelis iššūkis aviacijos pramonèje. Kaip ir bet kuriame kitame sektoriuje, aviacijos pramonei daro įtaką perèjimas prie skaitmeninimo. Atsiradus naujoms didžiujų duomenų, mašininio mokymosi ir dirbtinio intelekto technologijoms, aviacijos pramonè bando prie jų prisitaikyti. Dideli duomenys yra pagrindine sritis, kurioje dirba kiekviena oro linijų bendrovè, siekdama patobulinti savo produktų pasiūlą ir paslaugas bei laimèti konkurencinëje kovoje. Didieji duomenys padès oro linijų bendrovèms geriau suprasti savo klientų elgesị ir tai, kurią sritį jiems reikia tobulinti (MECCTI, 2018).

Dèl numatomo didelio keleivių skaičiaus augimo ir orlaivių skaičiaus didèjimo pramonèje bandoma daugybė technologijų - kuriami hibridiniai orlaiviai, ,iperkami“ viršgarsiniai orlaiviai ir dronai. Tai išbando ịvairios kompanijos visame pasaulyje, noredamos gauti kuo daugiau pajamų ir pelno. Pagal šiuo metu taikomą orlaiviu valdymo ir naudojimo būdą reikès daugiau pilotų ir keleivių salono ịgulos darbuotojų, kad būtų galima atliepti padidejusią paklausą. Vienas iš galimų sprendimo būdų pilotų trūkumui spręsti, kurio ieško oro linijos, yra vieno piloto kabinų kūrimas. Ši technologija laikoma viena iš spartaus augimo keliamų problemų sprendimo dalimi (ITF Global, 2020).

Rinkoje pradedami gaminti nauji orlaiviai. Pavyzdžiui, „737Max“ orlaivių šeima pateikia penkis variantus, o tai daugiau nei bet kuri produktų grupè istorijoje. „Airbus A320/1“ “ šima yra mažiau diversifikuota, tačiau tai gali pasikeisti, jei „Airbus“ paleis varikli A321, pramintą A322. Taigi, aviacijos pramonè susiduria su didžiuliu iššǔkiu, kad prisitaikytų prie šių naujų produktų (MECCTI, 2018). 
Tačiau technologinių inovacijų plètra transporto sektoriuje sukuria ne tik privalumus, bet ir iššūkius, su kuriais tiesiogiai susiduria ir Lietuvoje veikiantys didieji ūkio subjektai. VI „Oro navigacija“, valstybès įmonè „Lietuvos oro uostai“ ir kt., siekdamos patenkinti augančius rinkos poreikius ir tarptautinius reikalavimus ieško inovatyvių sprendimų veiklai vykdyti. Pavyzdžiui, Europos Sajunga inicijavo Europos oro eismo valdymo architektūros reformą, kuri leis restruktūrizuoti Europos oro erdvę, sukurti papildomų pajėgumų ir padidinti bendrą oro eismo valdymo sistemos efektyvumą. Todèl VI „Oro navigacija“ nemažai investuoja ị naujos įrangos ịsigijimą, mokslinių tyrimų vykdymą, o tai tiesiogiai daro įtaką TKA žmogiškiesiems ištekliams - jų pajègumui ir kvalifikacijai sertifikuoti naują įrangą ir užtikrinti profesionalią jos priežiūrą (TKA, 2019b).

Perejjimas prie nuotolinio skrydžių valdymo bokštų leidžia skrydžių valdymo centrus ịrengti atokiau nuo paties oro uosto ir, atsižvelgiant ị įdiegtą technologiją, suteikia galimybę vienu metu valdyti oro eismą keliuose oro uostuose. Tokiu būdu, sumažèja išlaidos, nes „nuotoliniai bokštai“ yra 30-40 proc. pigesni nei vietoje esantys bokštai, ir ịrengiančių nuotolinius bokštus oro uostų skaičius pamažu didėja. Kbbai stebimi mažesni oro uostai, nuotolinė oro eismo kontrolė leidžia vienam skrydžių vadovui vienu metu stebėti kelių oro uostų kilimo ir tūpimo takus. Pavyzdžiui, Norvegijoje nuotoliniai bokštai valdo iki 15 mažų oro uostų skrydžių srauto, dar 17 planuojama prijungti.

Nuotolinių bokštų poveikis skrydžių saugai priklausys nuo oro eismo kontrolès darbuotojų darbo sąlygų, taip pat nuo to, kiek jų darbą paspartins naujos technologijos. Kyla susirūpinimas tiek dèl oro eismo saugumo, tiek dèl ittemptų darbo sąlygų, kai naudojami 360 laipsnių ekranų su daugybe duomenų rodmenų ir tuo pačiu metu stebimas kelių oro uostų eismas. Tai pabrèžia poreikị atsižvelgti ị atitinkamą nuovargio ir streso lygio poveikị darbuotojams ir užtikrinti, kad technologijos jiems padètų, o ne juos pakeistų (ITF Global, 2020).

\subsection{Tvari plètra}

Aviacijos sektoriuje vis dar aktualios tvarios plètros tendencijos, ypač aplinkosaugos srityje. Europos Sajungos šalys turi pasiekti iškeltus strateginius tikslus, kad iki $2050 \mathrm{~m}$. aviacijos sektoriuje naudojami tvarūs ir mažai anglies dioksido išskiriantys degalai sudarytų 40 proc. ir iki $2050 \mathrm{~m}$. sujungti visus pagrindinio tinklo oro uostus su geležinkelių (pageidautina - greitujų traukinių) tinklu; užtikrinti, kad visi pagrindiniai jūrų uostai būtų tinkamai sujungti su krovinių vežimo geležinkeliais tinklu ir, kur įmanoma, su vidaus vandens kelių tinklu; iki 2020 įdiegti modernią oro eismo valdymo infrastruktūrą (SESAR) ir sukurti bendrą Europos aviacijos erdvę (TKA, 2019b).

Tuo tikslu tai pat yra kuriami naujos technologijos orlaiviai, pertvarkomi esami ir kuriami nauji oro uostai. Andrew Matters, IATA vyriausiojo ekonomisto pavaduotojas, teigia, kad aviakompanijoms reikès 40000 nauju orlaivių per ateinančius 20 metų, kurių vertė sieks 7 trilijonus USD, o tai reiškia, kad pramonè turi būti nuolat pelninga (IATA, 2019). Tačiau tik keturi iš 100 geriausių oro uostų neturètų pajègumų apribojimų per ateinančius 10 metų, jei keleivių srautas išliktų pastovus. Dauguma oro uostų jau dabar susiduria su sunkumais. Eurocontrol tyrimo duomenimis iki 2040 m. 1,5 mln. Europos skrydžių nebus įmanoma vykdyti dèl pajègumų problemų. Kitaip tariant, bus prarasta apie 8 proc. paklausos Europoje (IATA, 2019).

Dèl numatomo sektoriaus augimo, keliami nauji reikalavimai infrastruktūrai ir paslaugoms, todèl daugelis oro uostų yra atnaujinami arba plečiami. Keičiasi pati oro uosto koncepcija. Oro uostai nebebus laikomi tik išvykimo ar atvykimo taškais, jie taps vis labiau integruoti su restoranais, prekybos centrais ir kitomis laisvalaikio pramogomis.

Atsižvelgiant i augančius keleivių srautus, yra parengta Lietuvos oro uostų plètros strategija 2019-2022 m., kurioje planuojama oro uostų plètra (LOU, 2019). Ryškiausia Lietuvos oro uostų plètra prasidejo, kai savo veiklą mūsų šalyje pradèjo žemų kaštų oro bendrovės „Ryanair“ ir „Wizzair“. Po kilimo ir tūpimo tako rekonstrukcijos Vilniaus oro uoste imtasi terminalo modernizacijos, $2020 \mathrm{~m}$. iškils naujojo VIP terminalo su konferencijų centru projektas. 2022-aisiais metais numatoma baigti Kauno oro uosto keleivių terminalo atnaujinimą, po kurio žadama daugiau erdvės ir patogumo. Lietuvos oro uostai praneša, kad pagrindinių šalies oro vartų - Vilniaus terminale rekonstrukcija prasidès vasarị ir baigsis 2021 metais. Trečdalis numatomų išlaidų - $20 \mathrm{mln}$. EUR - bus skirta pagal tarptautinius reikalavimus privalomajai įrangai įsigyti bei atnaujinti, o apie $12 \mathrm{mln}$. EUR kainuos orlaivių perono ir riedejjimo takų rekonstrukcija (LOU, 2019). Palangos oro uoste 2020 metais planuojama taip pat pradèti rekonstrukciją, po kurios bus perplanuotos pastato erdvès bei padidintas terminalo pralaidumas. Imtis rekonstrukcijos verčia per pastaruosius penkerius metus oro uoste pustrečio karto išaugęs keliautojų skaičius (Gelžinis, 2019).

2019 metų pirmajame pusmetyje Lietuvos oro uostai skaičiavo aukštesnius nei praejusiais metais tuo pačiu laikotarpiu finansinius rezultatus. Bendros pajamos nuosekliai augo ir pasiekè 23,7 mln. Eur (16 proc. augimas). Labai džiugina, kad itin auga neaviacinès veiklos pajamos, kurios minètą pirmą pusmetị sudare beveik 40 proc. visų generuojamų pajamų. Siekiama, kad oro uostų pajamos iš abiejų šaltinių, t. y. aviacinès veiklos ir neaviacinės veiklos būtų kuo tolygesnès, toks santykis būtų labai sveikas tokiai organizacijai kaip oro uostai (Gelžinis, 2019).

\subsection{Besikeičiantys vartotojų poreikiai}

Klientai yra raktas ị bet kokio verslo augimą, o aviacijos pramonė taip pat stengiasi išlaikyti savo klientus. Tačiau klientai šiais laikais yra labai išrankūs ir išmanūs. Šiais laikais visi nešiojasi išmanųji telefoną su stabiliu interneto 
ryšiu, kuris palaiko ryši su likusiu pasauliu. Jeigu klientai nėra patenkinti teikiamomis paslaugomis ar pasiūlymais, jie tikrai pateiks neigiamų atsiliepimų apie bendrovę ir išplatins juos ịvairiose socialinès žiniasklaidos platformose. Jei tai nutinka, tai tikrai sugadina prekès ženklo įvaizdị ir verslą. Taigi, labiau personalizuotas bendravimas su klientais pagerins klientų aptarnavimą ir jų pasitenkinimo lygị.

Siekdamos išlikti konkurencingos, oro linijų bendrovės kaupia didžiuosius duomenis ir tobulina savo paslaugas bei pasiūlymus. Oro linijų bendrovès taip pat turi galimybę sukurti pokalbių svetaines, kuriose taikant dirbtinị intelektą galès geriau suprasti klientų poreikius ir nukreipti klientą į tinkamą paslaugų sritị. Tai taip pat leis oro transporto bendrovėms sumažinti savo skambučių centro išlaidas ir galès geriau padèti klientams. Pasitelkdamos didelius duomenis ir dirbtinị intelektą, oro linijų bendrovès gali žinoti visą svarbią informaciją apie savo klientus, jų pomėgius, mėgstamiausias kelionių vietas, kelionès laiką ir pan. Taigi, remiantis visa šia informacija, bus galima keleiviams suteikti labiau pritaikytas paslaugas, ir taip išlaikyti jų lojalumą (MECCTI, 2018).

Apibendrinant galima teigti, kad aviacijos pramonè yra labai didelis sektorius, todèl yra didžiulès galimybès jos plètrai. Kita vertus, aviacijos pramonei kyla nemenki iššūkiai, ir yra ieškoma racionalių sprendimų, kad klientams būtų suteiktos geriausios paslaugos, ir tuo pačiu užtikrintas sektoriaus augimas bei pelningumas. Pasitelkiant naujas technologijas, aviacijos pramonè taip pat pajègi igyvendinti naujas saugos ir saugumo, tvarios plètros reikalavimus.

Norint ịveikti visus šiuos iššūkius reikalingi kvalifikuoti aviacijos srities specialistai, gebantys prisitaikyti prie pokyčių.

\section{Aviacijos specialistų rengimas ir licencijavimas}

Aviacijos ir susijusiuose sektoriuose visame pasaulyje iš viso dirba apie $63 \mathrm{mln}$. specialistų. Apie $10 \mathrm{mln}$. specialistų dirba tiesiogiai aviacijos srityje (Lapinskas, 2019).

„Aviacijos specialistas - fizinis asmuo, turintis specialų aviacijos išsilavinimą ir tam tikrą kvalifikacijąa" (LR Seimas, 2020). Pagal Lietuvos profesijų klasifikatorių (LPK, 2012), kuris yra parengtas pagal tarptautinị standartinị profesijų klasifikatorių ISCO-08, yra išskiriamos šios aviacijos profesijos:

- Orlaivių pilotai ir kiti giminiškų profesijų specialistai;

- Skrydžių vadovai;

- Skrydžiu saugos elektronikos technikai;

- Orlaivių variklių mechanikai ir taisytojai.

Pagal LPK 2012 pateikiamą informaciją orlaivių pilotai ir kiti giminiškų profesijų specialistai valdo orlaivių, vežančių keleivius, paštą ir krovinius, mechaninès, elektrinès ir elektroninès įrangos veikimą, atlieka panašias užduotis prieš skrydį ir skrydžio metu. Skrydžių vadovai kontroliuoja ir valdo orlaivius ore ir žemėje, naudodami radijo, radiolokatorių ir šviesos sistemų ịrangą, taip pat teikia informaciją, kurios reikia orlaiviui pilotuoti. Skrydžių saugos elektronikos technikai atlieka technines užduotis, susijusias su orlaivių skrydžių ir aeronavigacijos kontrolès sistemų projektavimu, įrengimu, valdymu, technine priežiūra ir remontu. Orlaivių variklių mechanikai ir taisytojai montuoja, prižiūri ir taiso orlaivių variklius ir mazgus, pavyzdžiui, korpusus, hidraulines ir pneumatines sistemas, bei atlieka jų kapitalinį taisymą (LPK, 2012). Profesijų klasifikatorius išsamiai aprašo ir aviacijos specialistų atliekamas užduotis. Vertinant specialisto kompetencijas, klasifikatorių galima pasitelkti kaip pagalbinę priemonę, nustatant būsimojo specialisto žinias, gebèjimus bei ịūdžius, reikalingus atitinkamai profesijai. Panašiai aviacijos specialistai yra skirstomi ir kitose pasaulio šalyse. Pavyzdžiui, JAV Aviacijos specialistai yra skirstomi į tam tikras kategorijas: pilotai, orlaivių techninès priežiūros inžinieriai ir skrydžių valdymo specialistai (Byers, 2016).

Aviacijos specialistų rengimą ir mokymus pasaulyje ir Lietuvoje vykdo tik akredituotos mokymo ịstaigos (TKA, 2019a). Lietuvos aukštosios mokyklos rengia aviacijos srities specialistus, atsižvelgdamos ị reikalavimus jų kompetencijai ir šiuolaikinius technologinius pokyčius. Lietuvoje vykdomų aeronautikos inžinerijos studijų krypties studijų programų specialieji reikalavimai yra reglamentuojami Aeronautikos inžinerijos studijų krypties aprašu (LR Švietimo ministerija, 2015), kuriame teigiama, kad „Aeronautikos inžinerijos studijų krypčiai priklauso kai kurios specialybės, priskirtos Europos aviacijos saugos agentūros (EASA) reguliuojamų profesijų grupei, šių programų sampratą ir reikalavimus nustato jas reguliuojantys tarptautiniai civilinès aviacijos ir Lietuvos Respublikos teisès aktai“.

Aviacijos specialistų licencijavimas yra reglamentuojami tarptautiniais ir atitinkamos šalies teisès aktais. Nuo 2003 iki 2020 m. galiojo Lietuvos Respublikos Susisiekimo Ministro įsakymas „Dèl Lietuvos Respublikos civilinės aviacijos specialistų licencijavimo nuostatų patvirtinimo“, reglamentuojantis aviacijos specialistų licencijavimo tvarkas Lietuvoje. Nuo 2020 m. sausio 2 d. vadovaujamasi 2018 m. liepos 4 d. Europos Parlamento ir Tarybos reglamentais (ES) 2018/1139 dèl bendrujų civilinès aviacijos taisyklių, kuriuo ịsteigiama Europos Sajungos aviacijos saugos agentūra, iš dalies keičiami Europos Parlamento ir Tarybos reglamentai (EB) Nr. 2111/2005, (EB) Nr. 1008/2008, (ES) Nr. 996/2010, (ES) Nr. 376/2014 ir direktyvos 2014/30/ES ir 2014/53/ES bei panaikinami Europos Parlamento ir Tarybos reglamentai (EB) Nr. 552/2004 ir (EB) Nr. 216/2008, taip pat Tarybos reglamentas (EEB) Nr. 3922/91 bei Lietuvos Respublikos aviacijos ịstatymo Nr. VIII-2066 nauja redakcija. Pažymejjimus licencijuojamiems aviacijos specialistams išduoda Lietuvos transporto saugos administracija (LTSA), o 
kompetencijos yra tikrinamos Transporto kompetencijų agentūros (TKA). TKA paskiria egzaminuotojus tikrinti pretendentų teorines žinias ir praktinius gebejimus. Licencijos formą ir turinị nustato LTSA, atsižvelgdama i tarptautinius reikalavimus. Civilinès aviacijos specialisto licencija išduodama tik su kvalifikacijos ịrašu. Išduodamos šių rūšių civilinès aviacijos specialistų licencijos (TKA, 2019a):

- avialinijų transporto pilotų (skraidančių lèktuvais - ATPL(A), sraigtasparniais - ATPL(H);

- komercinès aviacijos pilotų (skraidančių lèktuvais - CPL(A), sraigtasparniais - CPL(H);

- pilotų mėgèjų (skraidančių orlaiviais, kurie neįeina ì ultralengvųų OL kategoriją, - lèktuvais PPL(A), sraigtasparniais - PPL(H);

- navigatoriu - FN;

- skraidančiujų inžinierių - F/EL $(\mathrm{A})(\mathrm{H})$;

- laisvojo aerostato pilotų - LA;

- skrydžių vadovų - SV;

- technikų / inžinierių / mechanikų - TI;

- sklandytojų - SK;

- pilotų mokinių, skrydžių vadovų mokinių - MO;

- skrydžio dispečerių - SD.

Bendruoju atveju pretendentai, pageidaujantys gauti atitinkamą civilinès aviacijos piloto licenciją arba kvalifikaciją, privalo:

- baigti mokymą TKA akredituotoje mokymo ịstaigoje ir pateikti baigimo dokumentus;

- išlaikyti TKA nurodytus profesinių žinių teorijos bei praktinių ịūdžių egzaminus;

- išlaikyti anglų kalbos egzaminą, pagal Tarptautinès Civilinės aviacijos organizacijos (toliau - ICAO) parengtus kalbos mokejjimo reikalavimus, kurie išdèstyti Tarptautinès Civilinès Aviacijos Konvencijos (Čikagos konvencija) 1 priede bei ICAO Kalbos igūdžių reikalavimų ịgyvendinimo vadove ir jo prieduose (Doc 9835-AN/453);

- pateikti nustatyta tvarka išduotą atitinkamos klasės galiojantị sveikatos pažymejjimą.

Pasak TKA specialistų, didelę ịtaką specialistų mokymui ir licencijavimui turès pilotus ir aviacijos inžinierius rengiančių mokymo organizacijų plètra. Orlaivių gamintojo „Boeing“ prognozėmis per artimiausius 20 metų Europos lèktuvų parkas paaugs 80 proc. pasiekdamas 8800 orlaivių skaičių. Tokiam aviacijos augimui patenkinti vien Europoje prireiks 146 tūkst. naujų pilotų. Todèl jau dabar matomas augantis naujų pilotų mokymų resursų poreikis, kuri Lietuvoje, o ir kitose pasaulio šalyse aviacijos pramoneje veikiančios ịmonès ketina užtikrinti steigdamos mokymo centrus (šių metų pabaigoje atidarytas ketvirtasis mokymų pastatas Vilniuje; steigiamas mokymų centras Vietname; pradedamas statyti - Kinijoje) (TKA, 2019a).

Civilinès aviacijos pasaulinè lèktuvų priežiūros rinka 2017 metais siekè apie 72 mlrd. dolerių, o kasmet vidutiniškai paauga po 3-4 proc. Skaičiuojama, kad 2013-2031 metais keleivinių lèktuvų prognozuojama pagaminti 27 tūkst., o komercinių sraigtasparnių skaičių planuojama praplèsti iki 40 tūkst. Prognozuojama, kad Europoje iki 2036 m. aviacijos inžinierių poreikis išaugs iki 118 tūkst. Lietuvoje šioje srityje šiuo metu yra apie 2000 darbuotojų - orlaivių remonto mechanikų, inžinierių ir elektronikos sistemų priežiūros specialistų. Specialistai yra itin paklausūs, o dèl jų konkuruoja ne tik Lietuvos, bet ir viso pasaulio kompanijos. Atsižvelgiant ị industrijos poreikius ir Lietuvai siekiant įsitvirtinti orlaivių remonto industrijoje bei toliau kurti aukštos pridètinès vertės darbo vietas, planuojama, kad parengiamų specialistų skaičius turi padvigubèti - nuo dabar parengiamų 150-200 iki beveik 400 specialistų per metus. Siekiant tai užtikrinti aviacijos inžinerijos specialistai pradèti rengti Kauno technologijos universitete (TKA, 2019a).

Tačiau pasaulinè praktika rodo, kad rengiant aviacijos specialistus labai svarbu ugdyti tas kompetencijas, kurios atliepia ateities rinkos tendencijas. Turkų mokslininkai Peksatici ir Ergun (2019) teigia, kad sparčiai augant aviacijos pramonei Turkijoje, labai padaugèjo universitetų, siūlančių aviacijos vadybos programas, ir universitetų, priimančių studentus. Šių programų tikslas - patenkinti kvalifikuoto personalo, kurio reikia augančiai aviacijos pramonei, paklausą ir prisidèti prie jos plètros. Tačiau nežinoma, kaip sėkmingai šie padaliniai vykdo savo misijas. Universitetai ir pramonè susiduria su skirtingu visuomenès spaudimu, lūkesčiais ir pramonès standartais. Be to, abi pusès turi skirtingą kultūrą, politiką ir institucinę logiką. Šie skirtumai daro ịtaką akademinio pasaulio ir pramonès santykiams formuoti ir valdyti. Minèto tyrimo (Peksatici ir Ergun, 2019) tikslas buvo ištirti dabartinius Turkijos aviacijos pramonès ir Turkijos universitetų aviacijos valdymo padalinių santykius ir suprasti, kaip jų lūkesčius ir vertybes formuoja institucinė dinamika ir institucinè logika. Išvados rodo, kad skirtinga aviacijos pramonès ir aviacijos valdymo programų logika lemia atotrūkị tarp to, ką vertina aviacijos pramonès vadovai, ir to, ką siūlo aviacijos vadybos programos. Dèl šios spragos absolventams kyla sunkumų ieškant darbo aviacijos pramoneje, be to, tai trukdo veiksmingam pramonès ir akademinės bendruomenės bendradarbiavimui (Peksatici ir Ergun, 2019).

Todèl labai svarbios tampa mokslininkų izžvalgos ir atliktų tyrimų išvados apie ateities aviacijos specialistų kompetencijas. 


\section{Mokslinès įžvalgos apie ateities aviacijos specialistų kompetencijas}

Mokslininkai atkreipia dèmesi ne tik ị didẻjantị aviacijos specialistų poreikị, bet ir ị šių specialistų kvalifikaciją, akcentuoja tai, kaip naujos technologijos keičia kompetencijas, kurios reikalingos aviacijos industrijoje.

\section{1. Žmogiškieji veiksniai ir civilinès aviacijos sauga}

Sąvoka ,Žmogiški veiksniai“ pamažu išpopuliarèjo, kai oro transporto pramonè pastebėjo, kad žmonių klaidos lyginant su mechaniniais gedimais, oro sąlygomis ar orlaivio užgrobimais yra viena iš pagrindinių avarijų bei incidentu priežasčių aviacijoje. Žmogiškieji veiksniai, tame tarpe ir pilotų klaidos, buvo užregistruoti kaip pagrindiniai avarijų veiksniai. Dažniausia žmogaus klaida yra nesugebèjimas organizuoti oro eismą derinant skirtingus oro eismo valdymo sistemos komponentus. Žmogiškieji veiksniai yra labai svarbūs aviacijos saugai. Paaiškèjo, kad žmogiškosios klaidos yra kritinės oro eismo valdyme ir jo priežiūroje. Žmogiškieji veiksniai daro didesni poveikị tiek saugumui, tiek aviacijos sektoriaus efektyvumui, lyginant su kitomis transporto rūšimis. Žmonių vaidmuo avarijose ar ịvykiuose yra reikšmingas, kaip nurodo daugelis autorių. Šis matmuo remiasi svarba keleiviu saugumui, aviacijos saugos kultūrai (Gordon et al., 2007; Mearns et al., 2013), pilotų ir personalo mokymams (Chen et al., 2009), ir efektyviai komunikacijai. Stresas ir žmogaus klaidos kabinoje yra didžiausias "indèlis", sukeliantis aviacijos avarijas. Nepaisant didelès komercinių ar karinių pilotų tyrimų bazès, nepakanka tyrimų, susijusių su stresais, sukeliamais pilotų darbo vietoje. Kilic ir Ucler (2019) atliko tyrimą, skirtą ištirti streso veiksnius, patiriamus pilotų rengimo universitete. Tam tikslui streso veiksniai buvo išskirti ir ịvertinti pokalbių su skrydžio instruktoriais metu. Taikant analitinès hierarchijos procesą (AHP) buvo sudaryta 3 kriteriju ir 12 subkriterijų hierarchija. Rezultatai parode, kad svarbiausias pilotu patiriamo streso kriterijus yra asmeniniai veiksniai, po kuriu seka organizaciniai ir aplinkos veiksniai. Be to, rezultatai atskleidè, kad pirmieji keturi streso veiksniai pasauliniame reitinge buvo susiję su žinių, meteorologinių sąlygų, asmenybès ir ịrenginių bei transporto priemonių kategorijomis, kurių svoris atitinkamai ịvertintas 0,195, 0,154, 0,11 ir 0,109.

Gorbachev, Shestakov ir Stefański (2019) vykdè asmeninių savybių svarbos profesinèje veikloje tyrimą. Buvo sudaryta komanda, kurioje dalyvavo daugiau nei šimtas specialistul. Pagal tyrimo duomenis nustatyta 20 aviacijos inžinieriaus profesinių ir asmeninių savybių svarba profesinèje veikloje (1 lentelè).

1 lentelè. Aviacijos inžinieriaus asmeninių savybių svarba profesinėje veikloje (Gorbachev et al., 2019)

\begin{tabular}{|l|l|}
\hline 1. Kompetencija & 11. Emocinis intelektas \\
\hline 2. Disciplina & 12. Empatija \\
\hline 3. Atsakomybe & 13. Bendravimo igūdžiai \\
\hline 4. Darbo organizavimas & 14. Draugiškumas \\
\hline 5. Sprendimų priėmimas pagal esamą situaciją & 15. Atvirumas \\
\hline 6. Gebėjimas numatyti situaciją & 16. Vizija \\
\hline 7. Efektyvumas & 17. Pasitikejjimas savimi \\
\hline 8. Tikslumas & 18. Taktiškumas \\
\hline 9. Atmintis & 19. Humoro jausmas \\
\hline 10. Nestandartinis mąstymas & 20. Tvarkingumas \\
\hline
\end{tabular}

Singh, Sharma, Chadha ir Singh (2019) tyrè kelių grupių veiksnių poveiki aviacijos saugos rodikliams. Pagrindinis šio tyrimo tikslas buvo išanalizuoti modeliuojamą daugelio veiksnių grupių poveikị saugos valdymo sistemai (SMS) ir žmogiškujų veiksnių (HF) įtaką civilinès aviacijos saugos (CAS) efektyvumui bei pabrěžti aplinkos veiksnių poveikị saugos rodikliams. Šiame tyrime buvo naudojamas struktūrinių lygčių modeliavimo metodas, skirtas ištirti veiksnius, kurie daro didelę ịtaką civilinès aviacijos saugos rezultatams. Tiksliau, šis tyrimas buvo atliktas remiantis 733 aviacijos saugos ekspertu pateiktais duomenimis. Vidutinis keliu veiksniu grupiu poveikis parodè sąryṣ̨̌ tarp saugos valdymo sistemos ir žmogiškujų veiksnių bei civilinės aviacijos saugos veiklos rodiklių. Šis tyrimas pateikia civilinès aviacijos sektoriui vertingos informacijos kuriant efektyvias strategijas, kaip pagerinti civilinès aviacijos saugos veiklą.

Siūlomas tyrimo modelis apima septynis elementus: orlaivio dizainą ir eksploatavimą (ADO), orlaiviu techninę priežiūrą (AM), aviacijos infrastruktūrą (AI), aplinkos veiksnius (EF), saugos valdymo sistemas (SMS), žmogiškuosius veiksnius (HF) ir civilinès aviacijos saugos (CAS) efektyvumą. Daroma prielaida, kad keturi saugos klimato veiksniai - orlaivio projektavimas ir eksploatavimas, priežiūra, aviacijos infrastruktūra ir aplinkos veiksniai - turi nemažą reikšmę saugos valdymo sistemoms (SMS) ir žmogiškiesiems veiksniams (HF). Kitaip tariant, saugos valdymo sistemos (SMS) ir žmogiškieji veiksniai (HF) veikia kaip tarpininkai tarp civilinès aviacijos saugos (CAS) veiklos veiksnių.

Žmogiškieji veiksniai yra viena iš pagrindinių aviakatastrofos priežasčių. Žmogiškieji veiksniai, tokie kaip personalo supratimas, keleivių informavimas apie saugą, ryšiai, mokymai ir kompetencija - dèl saugos, 
koordinavimo ir išteklių valdymo, grèsmių ir klaidų, tinkamas darbo krūvio valdymas, aplinka, padedanti darbuotojams. Siūloma, kad aukščiausioji vadovybė galètų daugiau laiko praleisti orlaivių techninès priežiūros bazèje ir oro uoste, siekiant pagerinti civilinès aviacijos saugos (CAS) veiklą. Be to, sinergiškai turètų dirbti administracijos ir saugos darbuotojai.

Orlaivių dizainas ir eksploatacija $\operatorname{ADO}(\beta=0,643)$ ir saugos valdymo sistema SMS $(\beta=0,466)$ daré didžiausią įtaką žmogiškiesiems veiksniams. Aviakompanijos galètų bendradarbiauti su gamintojais, dizaineriais, inžinieriais ir politikais, kad jie pateiktų pilotų lūkesčius ir patirtį tobulinant civilinès aviacijos saugos (CAS) veiklą. Be to, saugumas gali būti patobulintas gerinant orlaivių sertifikavimą ir užtikrinant nuolatinị tinkamumą skraidyti. Orlaivių remontas ir techninè priežiūra $\operatorname{AM}(\beta=0,321)$ turèjo trečiajj stipriausią poveikị žmogiškiesiems veiksniams, ir ketvirtasis stipriausias nustatytas saugos valdymo sistemos (SMS) $(\beta=0,103)$ poveikis. Orlaivių remontas ir techninė priežiūra (AM) apima standartus ir procedūras, tinkamą išteklių paskirstymą, orlaivių keliamo triukšmo mažinimą ir reikalingų detalių keitimą. AM ir HF tyrimo pagrindinis tikslas yra optimizuoti kintamuosius, darančius ịtaką žmogaus darbui techninès priežiūros ir apžiūros metu. Tyrimai optimizuojami integruojant daugelị sričių, kurios daro įtaką žmogiškiesiems veiksniams (HF) ir padeda aiškinantis, kaip individas gali dirbti efektyviau. Oro uosto infrastruktūra AI $(\beta=0,321)$ turèjo penktą stipriausią poveiki žmogiškiesiems veiksniams $(\mathrm{HF})$. AI faktorius apima naujausių technologijų naudojimą, tinkamas oro uostų ir oro eismo valdymą ir efektyvų oro prognozių sistemos ataskaitų teikimą, siekiant pagerinti civilinės aviacijos saugos (CAS) efektyvumą. Rezultatai taip pat parodè, kad didesnis civilinès aviacijos saugos (CAS) ir žmogiškujų veiksnių (HR) poveikis civilinès aviacijos saugos (CAS) našumui buvo nustatytas saugos valdymo respondentams, palyginant su skrydžių vadovų respondentais. Tai reiškia, kad skirtingos priemonės turi skirtingą poveiki skirtingų aviacijos specialistų veiklos efektyvumui civilinès aviacijos saugos (CAS) srityje.

Autoriai Buriak ir Ayarsb (2019) teigia, kad narkotikų ir alkoholio vartojimo problema yra aktuali ir aviacijos specialistų tarpe. Saugos Reglamentas aviacijoje numato taisykles, kaip kovoti su narkotikų ir alkoholio vartojimo pasekmėmis. Reglamentai taikomi maždaug 7200 su aviacija susijusių bendrovių ir su jomis susijusių paslaugų. Pasekmès už taisyklių nesilaikymą gali būti prarastos pajamos, baudų paskyrimas, sustabdyta ar atšaukiama įmonės veikla. Siekiant nustatyti specifinius rezultatus, buvo atlikta „Front End Analysis“ (FEA) ir pritaikytos penkios švietimo programos esamoms problemoms spręsti. Programų vertinimas buvo atliekamas naudojant pertraukiamų laiko eilučių (ITS) modeliavimą. Rezultatai parodè reikšmingą $(p<0,05)$ neatitikimų sumažèjimą visuose penkiuose modeliuose su mažu ar vidutiniu efektų dydžiu. Remiantis santykinio poveikio vertemis buvo nustatyta, kad baudos sumažejo nuo 47 proc. iki 16 proc. Faktinis sankcijų skaičius lyginant laikotarpi iki mokymų ir po jų sumažèjo 24,21 proc.

\section{2. Žmogus ir dirbtinis intelektas aviacijoje}

Burns ir Bonaceto (2020) tyrimo metu sukūrè empirinị žmogaus patikimumo modelị (HRA) bendrosios aviacijos srityje, naudojant tikimybinę analizę, bei rizikos įvertinimo modelį (PRA) pagal istorinius avarijų rodiklius. Kuriant PRA/HRA modelį, buvo lyginami su retrospektyvia analize susiję nelaimingų atsitikimų dažnio duomenys su perspektyvia žmogaus veiklos analizėje taikomais patikimumo ir skrydžių saugos duomenimis, naudojant „Digital Copilot" pilotų sistemos prototipą.

Nominaliosios žmogiškujų klaidų tikimybès (HEP) analizès sukurta sistema taikoma pagal tris pagrindinius parametrus: žinias, taisykles ir igūdžius. Bendrojoje aviacijoje vienas pilotas (paprastai skrenda be antrojo piloto) tuo pat metu turi atlikti ịvairias informacijos apdorojimo užduotis bei valdyti orlaivị ịvairiose skrydžio fazèse. Ši informacijos apdorojimo užduotis apima: informacijos srauto skenavimą, diagramas, kontrolinius sąrašus, vadovus ir orų ataskaitas, skrydžio pokyčius, atsižvelgiant ị oro sąlygas ir degalų atsargas, bendravimą su skrydžių vadovais. Tobulèjant bendrosios aviacijos skrydžių saugai vyko bandymai norint išspręsti darbo krūvio taikant igulos išteklių valdymo koncepcijas komercinèje aviacijoje problemą. Pilotai skraidė su dirbtiniu intelektu ir paskyre jam atlikti atitinkamas užduotis reikalingas skrydžio metu.

Buvo sukurtas mobiliosios skaičiavimo programos prototipas, žinomas kaip „Digital Copilot“, skirtas demonstruoti pagalbos teikimą pilotams, vykdant informacijos apdorojimo užduotis. Naudodama kalbos atpažinimo sąsają, programa supranta, jog reikia vykdyti komandas, kurias perduoda pilotas.

Oro erdvès tyrinejjimų instituto (Aerospace Technology Institute - ATI) $2019 \mathrm{~m}$. paskelbtame 12-ajame INSIGHT leidinyje „The Single Pilot Commercial Aircraft“ analizuojamas aviacijos pramonès siekis sukurti vieno piloto valdomus orlaivius. Apžvelgtos technologinio automatizavimo ir autonominio valdymo galimybės kuriant šio tipo orlaivius, tačiau akcentuojama, kad kiti veiksniai turi svarbesnę įtaką šių technologijų proveržiui. Ekonomika, paklausa, prognozuojamas pilotų trūkumas ir galimas poveikis aviacijos mokymams vaidina didžiuli vaidmeni judant mažiau skrydžio igulos reikalaujančių technologijų link. Inovacijų ir skrydžio valdymo technologijų tobulinimas yra neatsiejama šios idejos igyvendinimo dalis užtikrinant efektyvias ir saugias vieno piloto operacijas, kuriose nuotoliniu būdu būtinai kartu dalyvautų ir asistuojantis žmogus - ko-pilotas ar autonominė kopilotavimo sistema žemejje - skrydžių valdymo centre ar kitame orlaivių valdymo padalinyje, taip sumažinant igulos narių skaičių ore. 
Autoriai teigia, kad savaime suprantama, kad kai ekipažas yra paskirstytas tarp oro ir žemès, galimybių sumažinti orlaivių eksploatavimo išlaidas yra mažiau. Tačiau vieno piloto orlaivis daug labiau priklausytų nuo didelio integralumo bei palaikymo iš žemės ir saugių duomenų nuorodų. Visų pirma, tai didintų oro eismo valdymo ir kontrolès darbuotojų skaičių ir keistų jų kompetencijas žemèje. Gali būti, kad atliekant operacijas būtų mažiau lankstumo, ir tokia orlaivių pilotavimo sistema gali sukurti sudėtingas organizacines, mokymo ir licencijavimo problemas - gali prireikti naujos kvalifikacijos personalo, atsakingo už orlaivio valdymo sistemos komponentus žemejje). Galiausiai šią technologiją gali greitai pakeisti vieno piloto igulos orlaiviai, naudojantys autonomines kopilotavimo sistemas. Keleivių nuomonès tyrimai rodo, kad vieno piloto orlaivis su tokia konfigūracija yra priimtinesnis nei bepiločiai - vien tik dirbtinio intelekto sistemų valdomas lèktuvas (Miller, 2019).

Tačiau ir automatizuotoms, ir autonominėms sistemoms yra reikalingas žmogaus, nustatantis tikslus ir stebintis sistemą. Šiuolaikiniam skrydžio valdymui, nors ir turint aukštą automatizavimo laipsnị, vis tiek reikia skrydžio igulos priežiūros ir stebėjimo, o pilotai turi sugebėti įsikišti, kai dẻl išorinių veiksnių reikia pakeisti pradinị skrydžio planą. Tas pats galios ir vieno piloto lèktuvui, nepriklausomai nuo to, kaip bus diegiama ši technologija. Svarbu pripažinti, kad žmogaus vaidmuo yra ne tik kritiškai svarbus prižiūrint sistemas, turinčias mažesni ar didesnị savarankiškumą, bet ir teikiant jai pagrindinius duomenis, užtikrinančius galutini sistemos rezultatą. Automatika ir (arba) autonomija turètų būti grindžiama tuo, kas yra sudėtingiau atlikti žmogui (kaip pavyzdys, užduotys, reikalaujančios ilgo budrumo, protinio nuovargio, psichinès perkrovos), ir tais funkcionalumais, kur yra aiškiai matomi žmogaus privalumai - pvz., taktinių sprendimų prièmimas. Trys pagrindinès žmogiškosios problemos, kurias reikia spręsti vieno piloto valdomose operacijose, būtų: darbo krūvis, sistemos ir skrydžio valdymas; taktinis ir strateginis skrydžių planavimas; ir klaidų išvengimas.

Be technologinio, ekonominio, normatyvinio ir visuomeninio pripažinimo vieno piloto koncepcija turètų pasekmių daugelyje organizacinių oro linijų sričių. Žmogiškujų užduočių perskirstymas kelia svarbių problemų tokiose srityse kaip personalo atranka ir mokymai. Pagrindinis klausimas yra tai, kiek žmonių reikès žemėje, kad palaikytų pilotų operacijas ore (bet kurioje orlaivio konfigūracijoje)?

Iškyla nemažai personalo atrankos problemų. Dabartinėje sistemoje pilotai iš pradžių mokosi ir igyja antrųjų pilotų kvalifikaciją. Kai antrieji pilotai igyja pakankamai patirties, gali pasirinkti orlaivio kapitono mokymus. Kadangi vieno piloto koncepcijos orlaiviuose antrojo piloto vaidmens nebelieka, kyla klausimas, kaip pavieniai lakūnai igytų reikiamos patirties, kad iš karto galètų saugiai ir atsakingai imtis kapitono pareigų. Kaip to jie bus išmokyti? Visi lakūnai tuo atveju iš tikrujų turètų būti tik kapitonai. Tačiau orlaivio vadas yra atsakingas ne tik už skraidymą orlaiviu, bet ir taip pat už priimamus pagrịstus saugos sprendimus, susijusius su operacijomis, igulos valdymu ir keleivių situacijomis. Taip pat kyla klausimas, kokia patirtis ir kvalifikacija būtų reikalinga antžeminiam personalui ir ar jie būtų ịdarbinti ne iš esamo oro linijų išteklių fondo?

Naujų skrydžio kabinos sistemų ir veiklos koncepcijų poveikis pareikalaus kitokio požiūrio ị individualų ir komandini mokymą. Paskirstytiems sprendimams priimti reikalingos naujos mokymo priemonès (simuliatoriai, kompiuterinis mokymas, simuliacijos oro operacijų kambariuose pasitelkiant sprendimų paramos sistemas) ir antžeminio personalo, ir pilotų mokymams, didinant teikiamų mokymų sudėtingumą. Žvelgiant iš socialinès ir organizacinès perspektyvos, kyla klausimas, kokią ịtaką šios naujo tipo operacijos turès esamai oro linijų organizacinei kultūrai (pvz., paaukštinimui pareigose pagal darbo stažą). Gali būti net reikalavimas pakeisti žinias, igūdžius ir gebėjimus, nuo tradicinių igūdžių rinkinio (pvz., skraidymą rankiniu būdu) ì tą, kuris pabrěžia deleguotus igaliojimus (pvz., sistemų prižiūrejjimas ir stebejjimas). Tai rodo reikšmingą kompetencijų pokytị nuo praktikoje ịgytų igūdžių prie žiniomis pagrịsto samprotavimo. Norint valdyti vieno ịgulos nario komercinị orlaivị, reikès perskirstyti užduotis tarp oro ir žemès, piloto ir mašinos.

Studijos autorių nuomone, vieno piloto orlaivis gali būti pirmiausia išbandomas krovinių gabenimo atveju. Tai suteiktų galimybę tobulinti reikalingas technologijas, išbandyti naują požiūrị ị saugą, sertifikavimo ir projektavimo procesus ir padètų ieškoti saugaus orlaivio skrydžio parametrų atstatymo galimybių piloto neveiksnumo atveju. Ir toli gražu nesumažindama pilotų poreikio, ši koncepcija iš tikrujų gali padidinti poreikị. Parimal Kopardekar, NASA Ames tyrimų centro koncepcijų ir technologijų plètros projekto projektų vadovas, pažymëjo, kad vieno piloto operacijos yra ,poliarizuojanti tema“. Jo manymu, jei būtų galima ígyvendinti vienos ịgulos operacijas, sumažètų išlaidos vienam keleiviui už mylią, o kartu sumažètų ir bilietų kainos, kurioms sumažèjus padidètų paklausa, todèl ateityje gali prireikti dar daugiau pilotų ir dar daugiau orlaivių.

Apibendrinant pateikiamos šios išvados:

- Pagrindiniai veiksniai, lemiantys tolesni skrydžio kabinų igulų skaičiaus mažinimą, vykdant komercines operacijas, greičiausiai kyla ne iš technologijų pusès, bet siekiant sumažinti išlaidas, patenkinti paklausą ir sprendžiant igulos poreikio klausimus.

- Perejjimas prie labiau automatizuotų ar autonominių valdymo sistemų dar labiau padidintų aviacijos saugą ir palaikytų naujus pokyčius svarbiausiose pilotų kabinos technologijų srityse.

- Reikètų vengti galimybės pakeisti daugiapilotę igulą į vienpilotę, visiškai nekeičiant technologijų, pilotų kabinos darbo vietos ir skrydžių valdymo sistemų. 


\subsection{Iššūkiai aviacijos specialistams: JAV ir JK atvejis}

JAV ir Jungtinė Karalyste užima atitinkamai pirmą ir trečią vietą pagal aviacijos rinkos dydį pasaulyje. Abi šalys turi iššūkius pritraukti naujų darbuotojų pilotuoti ir prižiūrèti orlaivius, valdyti oro uostus, kontroliuoti oro eismą, statyti ir valdyti terminalus bei atlikti visus kitus darbus, susijusius su sauga, inovatyviuju technologiju aviacijos pramoneje plètra. Eby ir Lewis (2019) atliko žmogiškujų resursų tyrimą JAV ir JK aviacijos pramonès sektoriuose ir apibendrino iššūkius, su kuriais susiduria aviacijos specialistai, remiantis aviacijos asociacijų ir susijusių grupiu informacija, nepriklausomais akademiniai tyrimais, vyriausybiniais ir naujienu pranešimais, taip pat buvo analizuojami gerosios praktikos atvejai, šių šalių atvirujų duomenų informacijos šaltiniai. Didelè konkurencija dèl darbuotojų, kintantis aukštos kvalifikacijos darbo pobūdis, užtarnauto poilsio išeinanti karta daro didelę ịtaką daugelio šaliu šiuolaikinei ekonomikai, - visa tai yra aktualu ir šiose šalyse. Deja, pragmatiški politikos sprendimai mažai turi ịtakos visapusiškai sprendžiant darbo jègos iššūkius visuose aviacijos subsektoriuose.

Bendros autoriu (Eby ir Lewis, 2019) įžvalgos, svarbios norint suprasti, kaip keisis aviacijos pramonè ir ateities darbo jèga, yra šios:

- Aviacijos pramonè susidurs su daugeliu iššūkių, susijusių su darbo jèga, nes keleivių skaičius oro transportu ateinančiais metais augs. Darbuotojų perspektyvos skiriasi priklausomai nuo specialybès, bet tikimasi, kad darbo vietų skaičius aviacijoje augs.

- Nežinoma, kokiu laipsniu technologijos pakeis darbuotojus, tačiau technologijos turès ịtakos visų aviacijos darbuotojų darbo pobūdžiui. Pramonè privalo užtikrinti, kad nauji darbuotojai ir esamas personalas būtų apmokyti naudoti naujas technologijas.

- Darbo jègos demografija keičiasi, nes dabartinių darbuotojų karta ruošiasi išeiti i pensiją, ir karta, kuri jas pakeis, yra ịvairesnè. Norẻdama užpildyti būsimas darbo vietas, pramonè turès apeliuoti i platesnę demografiją.

- Po daugelio iššūkių, dèl kurių 2001-2009 m. buvo sumažintos išlaidos, aviacijos pramoné pradèjo didinti atlyginimus ir skirti skatinamąsias premijas, kad pritrauktų ir išlaikytų darbuotojus.

- Aviacijos pramoné konkuruoja dèl darbuotojų sektoriaus viduje, su kitomis profesijomis ir kitomis šalimis. Darbuotojai pereina $\mathfrak{i}$ kitas pramonès šakas, persikelia ị kitas šalis, todėl taikoma praktika įdarbinant darbuotojus iš kitų sektorių (pvz., oro linijų bendrovès samdo karinius pilotus).

Tyrimo autoriai (Eby ir Lewis, 2019) pateikia unikalius iššūkiu apibendrinimus, atskleisdami skirtinguose aviacijos sektoriuose dirbančių aviacijos specialistų veiklos specifikos ir darbo sąlygų ateities ypatumus (2 lentelè).

2 lentelè. Iššūkiai, su kuriais susiduria aviacijos specialistai, dirbantys skirtinguose aviacijos sektoriuose (Eby ir Lewis, 2019)

\begin{tabular}{|c|c|}
\hline $\begin{array}{l}\text { Avi } \\
\text { speci }\end{array}$ & Iššūkiai \\
\hline Pilotai & $\begin{array}{l}\text { - Nėra aišku, ar JAV ir JK tikrai trūksta pilotų. Tačiau dèl padidèjusios oro kelionių paklausos } \\
\text { prognozuojamas pilotu poreikio augimas kaip ir daugelyje pasaulio šalių. Šią tendenciją papildo ir } \\
\text { dabartiniu pilotų išejimo pensiją problema bei labai aukšta kvalifikacijos kartelè norintiems tapti } \\
\text { šios profesijos atstovais. } \\
\text { - Mokymosi išlaidos taip pat gali tapti kliūtimi daugeliui naujų pretendentų siekti piloto karjeros, } \\
\text { nors avialinijos ir didino atlyginimus skirdami premijas, kad profesija taptų konkurencingesnè. } \\
\text { - Sumažėęs pilotų srautas pereinančių iš regioninių vežèju ir karinių oro pajėgu nebepadengia } \\
\text { trūkstamos darbo jègos profesionaliose avialinijose poreikio. }\end{array}$ \\
\hline Skrydžių vadovai & $\begin{array}{l}\text { - Darbo jègos iššūkiai yra opiausi JAV, bet taip pat ir JK. } \\
\text { - Valdymo skirtumai - JAV skrydžiu valdymo sistema priklauso viešajam sektoriui, o JK - sistema } \\
\text { veikia kaip viešojo ir privačiojo sektoriu partneryste. Tai gali turèti įtakos kiekvienos šalies } \\
\text { galimybems išlaikyti, įdarbinti ir apmokyti reikalingą personalą. } \\
\text { - Griežtesni reikalavimai specialistams JAV negu JK, todèl gali JAV gali atsirasti didesnis darbo } \\
\text { jègos trūkumas teikiant saugias bei kokybiškas oro eismo valdymo, kontrolès bei navigacijos } \\
\text { paslaugas. } \\
\text { - Abiejose šalyse naujus ir esamus darbuotojus reikès apmokyti dirbti su naujausiomis techno- } \\
\text { logijomis. }\end{array}$ \\
\hline $\begin{array}{l}\text { Orlaivių techninès } \\
\text { priežiūros, remonto } \\
\text { ir kapitalinio } \\
\text { remonto specialistai }\end{array}$ & 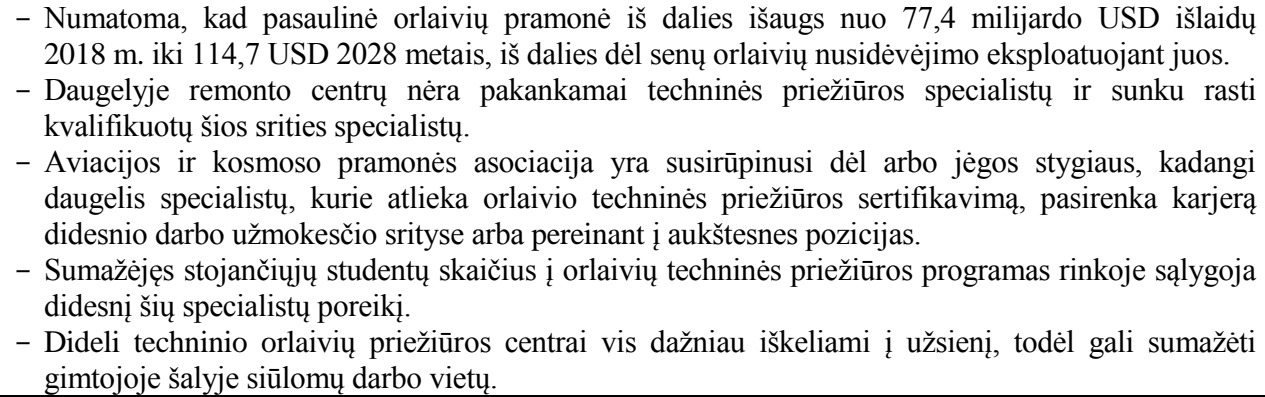 \\
\hline
\end{tabular}




\begin{tabular}{|c|c|}
\hline $\begin{array}{l}\text { Aviacijos } \\
\text { specialistai }\end{array}$ & Iššūkiai \\
\hline $\begin{array}{l}\text { Oro uosto } \\
\text { darbuotojai }\end{array}$ & $\begin{array}{l}\text { - Norint patenkinti augančią oro transporto paklausą, oro uostams reikės papildomų darbuotojų. } \\
\text { Automatizuotos sistemos ilgainiui pakeis darbuotojų atliekamas funkcijas. } \\
\text { - Panašu, kad darbo užmokestis ivaairiose oro uostų srityse didejja. Stabili ekonomika su žemu } \\
\text { nedarbo lygiu sukuria palankią aplinką kolektyvinėms deryboms dèl didesnio darbo užmokesčio ir } \\
\text { kitoms profesinių sajungų pastangoms reikalauti geresnių darbo sąlygas sukūrimo abiejose šalyse. } \\
\text { - JAV saugumo tikrintojus daugiausia samdo federalinè vyriausybè. Nors informacijos yra mažai, } \\
\text { bet palyginus šių darbuotojų darbo užmokestị su jų privačiojo sektoriaus kolegomis, būtų galimybė } \\
\text { palyginti santykines viešojo ir privačiojo sektoriaus tikrintojų sąnaudas ir veiklos efektyvumą. }\end{array}$ \\
\hline Skrydžių palydovai & $\begin{array}{l}\text { - Galima teigti, kad skrydžio palydovų netrūksta. Rekordinis pareiškèjų procentas kreipiasi dèl labai } \\
\text { konkurencingų darbo vietų. } \\
\text { - Skrydžio palydovų streikai dèl darbo užmokesčio ir darbo sąlygų pasiekè rezultatų. } \\
\text { - Didžioji dalis palydovų yra moterys, ir ši profesija turi ilgą istoriją kovojant su seksualiniu } \\
\text { priekabiavimu prie moterų. }\end{array}$ \\
\hline Orlaivių gamintojai & $\begin{array}{l}\text { - Dėl oro kelionių augimo padidès naujų orlaivių paklausa, Tačiau svarbūs geopolitiniai ịvykiai kaip } \\
\text { „Brexit“ JK ir pasaulinio prekybos karo keliamos grèsmès JAV gali paveikti pagrindinius aviacijos } \\
\text { gamintojus. } \\
\text { - Aviacijos pramonè susijusi su daugybe antrinių sričių, turinčių skirtingus išsilavinimo ir } \\
\text { licencijavimo reikalavimus. Nepaisant to, potencialūs darbuotojai turès būti mokomi gamtos } \\
\text { mokslų, technologijų, inžinerijos ir matematikos, taip pat bendresnių darbo igūdžių, siekiant } \\
\text { pritraukti ir išlaikyti kvalifikuotą darbo jëgą. }\end{array}$ \\
\hline
\end{tabular}

Galima teigti, kad išvardinti iššūkiai aviacijos specialistams JAV ir JK atspindi bendras tendencijas, kurios stebimos pasaulyje, Europoje, ir Lietuvoje. Todèl šiomis ịžvalgomis ir rekomendacijomis galima vadovautis kaip gairèmis išsamiau tiriant aviacijos specialistų poreikị bei jų ateities kompetencijas ir kitose šalyse, tame tarpe ir Lietuvoje.

\section{Išvados}

1. Atsižvelgiant ị Pasaulio, Europos bei Lietuvos aviacijos plètros tendencijas galima teigti, kad aviacijos sektorius turi spręsti kylančius iššūkius, susijusius su aviacijos sauga, technologiniais pokyčiais, tvarios plètros reikalavimais bei besikeičiančiais vartotoju poreikiais.

2. Aviacijos specialistų kompetencija yra vertinama pagal teisės aktais apibrèžtus reikalavimus: baigtus mokymus akredituotoje ịstaigoje; išlaikytus reikalingus teorijos ir praktikos egzaminus; išduotą atitinkamos klasės sveikatos pažymėjimą; išlaikytą atitinkamą kalbos lygio testą. Tačiau ne vien formalūs kriterijai lemia aviacijos specialistų veiklos efektyvumą.

3. Mokslininkų atlikti tyrimai parodè, kad asmeninès žmogiškosios savybès taip pat yra svarbios aviacijos specialistų darbe, ypatingai užtikrinant skrydžių saugą. Orlaivio dizainas ir eksploatavimas, orlaivių techninè priežiūra, aviacijos infrastruktūra, aplinkos veiksniai bei taikoma saugos valdymo sistema turi įtakos žmogiškiesiems veiksniams pasireikšti, tuo pačiu ir civilinès aviacijos saugos efektyvumui.

4. Dirbtinio intelekto sistemos padeda orlaivių pilotams atlikti didelio informacijos srauto apdorojimo užduotis, ịvertinti situaciją ir priimti teisingus sprendimus. Perejimas prie labiau automatizuotų ar autonominių valdymo sistemų dar labiau padidintų aviacijos saugą ir palaikytų naujus pokyčius svarbiausiose vienpiločių orlaivių technologijos srityse.

5. Aviacijos pramonė susidurs su daugeliu iššūkių, susijusių su darbo jèga, nes keleivių skaičius oro transporte ateinančiais metais augs. Nežinoma, kokiu laipsniu technologijos pakeis darbuotojus, tačiau technologijos turès įtakos visų aviacijos darbuotojų darbo pobūdžiui. Pramonè privalo užtikrinti, kad nauji darbuotojai ir esamas personalas būtų apmokyti naudoti naujas technologijas.

6. Aviacijos pramonė konkuruoja dèl darbuotojų sektoriaus viduje, su kitomis profesijomis ir kitomis šalimis. Aviacijos specialistams keliami labai aukšti profesiniai reikalavimai, todèl aviacijos sektorius turètų skirti finansines ir kitas paskatas išlaikyti esamus darbuotojus, pritraukti ir ugdyti naujus talentus ateičiai.

\section{Literatūra}

Airbus. (2019). Global market forecast. https://www.airbus.com/aircraft/market/global-market-forecast.html Boeing. (2019). Pilot and technician outlook. https://www.boeing.com/commercial/market/pilot-technician-outlook/

Buriak, S. E., \& Ayars, C. L. (2019). Evaluation of a drug and alcohol safety education program in aviation using interrupted time series and the Kirkpatrick framework. Evaluation and Program Planning, 73, 62-70.

https://doi.org/10.1016/j.evalprogplan.2018.11.003 
Burns, K., \& Bonaceto, C. (2020). An empirically benchmarked human reliability analysis of general aviation. Reliability Engineering \& System Safety, 194, 1-10. https://doi.org/10.1016/j.ress.2018.07.028

Byers, D. A. (2016). The aviation workforce of tomorrow where are they needed - and where will they come from? http://onlinepubs.trb.org/Onlinepubs/trnews/trnews304feature.pdf

Chen, C. C., Chen, J., \& Lin, P. C. (2009). Identification of significant threats and errors affecting aviation safety in Taiwan using the analytical hierarchy process. Journal of Air Transport Management, 15(5), 261-263. https://doi.org/10.1016/j.jairtraman.2009.01.002

Eby, B., \& Lewis, P. (2019). Aviation workforce challanges in the US and UK. https://www.enotrans.org/wpcontent/uploads/2019/03/3.26-US-UK-Aviation-Workforce_final.pdf

Gelžinis, M. (2019). Kokia yra Lietuvos oro uostu plètros strategija: kq verta žinoti? https://www.15min.1t/pasauliskiseneje/naujiena/kelioniu-ekspertas/kokia-yra-lietuvos-oro-uostu-pletros-strategija-ka-verta-zinoti-638-1247576?

Gorbachev, O., Shestakov, V., \& Stefański, K. (2019). Assessment of professionally important qualities aviation technical staff. AIP Conference Proceedings, 2077(1), 020022. https://doi.org/10.1063/1.5091883

Gordon, R., Kirwan, B., Mearns, K., Kennedy, R., \& Jensen, C. L. (2007). A safety culture questionnaire for European Air Traffic Control. http://www.eurocontrol.int

IATA. (2019). The challenges to growth. Retrieved from International Air Transport Association website: https://airlines.iata.org/news/the-challenges-to-growth

IATA. (2018). Future of the airline industry 2035. Retrieved from International Air Transport Association website: https://www.iata.org/contentassets/690df4ddf39b47b5a075bb5dff30e1d8/iata-future-airline-industry-pdf.pdf

ITF Global. (2020). Challenges and opportunities in aviation. Retrieved from International Transport workers Federation website: https://www.itfglobal.org/en/focus/automation/challenges-and-opportunities-in-aviation

Kilic, B., \& Ucler, C. (2019). Stress among ab-initio pilots: A model of contributing factors by AHP. Journal of Air Transport Management, 80, 1-9. https://doi.org/10.1016/j.jairtraman.2019.101706

Lapinskas, Ž. (2019). I trilijonine aviacijos industrija - vis daugiau moteru. https://www.lrt.lt/naujienos/mokslas-irit/11/842577/i-trilijonine-aviacijos-industrija-vis-daugiau-moteru

LOU. (2019). Lietuvos oro uostu pletros strategija 2018-2021 m. www.lou.1t

LTOU. (2019). VI Lietuvos oro uostai 2019 metu 6 mènesiu tarpinès finansinès ataskaitos, parengtos pagal tarpautinius finansinés atskaitomybès standartus, priimtus taikyti Europos Sajungoje. 2019-08-08 Nr. 8F-1151. https://www.ltou.lt

LPK. (2012). Lietuvos profesiju klasifikatorius. http://www.profesijuklasifikatorius.lt/

LR Seimas. (2020). LR aviacijos ịstatymas. Valstybès žinios, 2000-11-03, Nr. 94-2918. https://e-seimas.lrs.lt/portal/legalActEditions/lt/TAD/TAIS.112075?faces-redirect=true

Lietuvos Respublikos švietimo ir mokslo ministerija. (2015). Lietuvos Respublikos švietimo ir mokslo ministro įsakymas dèl inžinerijos studijų krypčių grupès aprašo patvirtinimo 2015 m. rugsèjo 10 d. Nr. V-964. TAR, 2015-09-11, Nr. 13746. https://e-seimas.lrs.lt/portal/legalAct/lt/TAD/48aa06b058b711e5a9129f08109b20ec/asr

Mearns, K., Kirwan, B., Reader, T. W., Jackson, J., Kennedy, R., \& Gordon, R. (2013). Development of a methodology for understanding and enhancing safety culture in Air Traffic Management. Safety science, 53, 123-133.

MECCTI. (2018). Current challenges in the airline industry 2018. https://www.mecabincrew.com/2018/03/12/currentchallenges-in-the-airline-industry-2018/

Miller, T. (2019). Explanation in artificial intelligence: Insights from the social sciences. Artificial Intelligence, 267, 1-38. https://doi.org/10.1016/j.artint.2018.07.007

Peksatici, Ö., \& Ergun, H. S. (2019). The gap between academy and industry - A qualitative study in Turkish aviation context. Journal of Air Transport Management, 79, 1-14. https://doi.org/10.1016/j.jairtraman.2019.101687

Singh, V., Sharma, S. K., Chadha, I., \& Singh, T. (2019). Investigating the moderating effects of multi group on safety performance: The case of civil aviation. Case Studies on Transport Policy, 7(2), 477-488. https://doi.org/10.1016/j.cstp.2019.01.002

TKA. (2019a). Aviacijos specialistų licencijavimas. Prieiga per Tranporto kompetencijų agentūros tinklalapị: https://tka.lt/oro-transportas/katalogas/licencijavmo-informacija/

TKA. (2019b). Viešosios įstaigos Transporto kompetencijų agentūros 2020-2024 metu strateginis veiklos planas. Prieiga per Tranporto kompetencijų agentūros tinklalapị: https://tka.lt/assets/uploads/sites/2/2019/08/TKA-2020-2024-m.strateginis-veiklos-planas.pdf

\title{
AVIATION SECTOR CHALLENGES FOR FUTURE TRAINING OF SPECIALISTS
}

\author{
Liudmila LOBANOVA, Rytis APANAVIČIUS
}

\begin{abstract}
The paper discusses the challenges facing the aviation industry that are changing the need for future professionals. The first part of the article analyzes the challenges of the aviation sector in the world and in Lithuania in terms of safety and security, new technologies, sustainable development, and changing user needs. The second part provides an analysis of the aviation training and licensing system, highlighting the legal and market requirements for aviation specialist competencies. The third section provides scientists insights into the future challenges of the demanding competencies of aviation professionals: human factors and their impact on aviation safety, the compatibility and reliability of human and artificial intelligence pilots in aviation, and the challenges facing aviation professionals in
\end{abstract}


different aviation sectors. Research carried out by scientists has shown that personal human qualities are also important in the work of aviation professionals, particularly in ensuring flight safety. Artificial intelligence systems help aircraft pilots perform large-scale information processing tasks, assess the situation and make the right decisions. The move to more automated or autonomous control systems would further enhance aviation safety and support new developments in key areas of single-pilot aircraft technology. The findings state that the aviation industry will face many challenges related with the workforce. It is not known to what extent technology will replace the professionals, but technology will affect the nature of the work of all aviation specialists, thus, industry must ensure that new and existing staff have the competences not only required by legal regulations but relevant in today's aviation market as well.

Keywords: aviation, competencies of specialists, human factors, technologies. 